NBER WORKING PAPER SERIES

FINANCIAL DEPENDENCE AND GROWTH

Raghuram G. Rajan

Luigi Zingales

Working Paper 5758

\author{
NATIONAL BUREAU OF ECONOMIC RESEARCH \\ 1050 Massachusetts Avenue \\ Cambridge, MA 02138 \\ September 1996
}

We thank Gene Fama, Peter Klenow, Krishna Kumar, Canice Prendergast, Andres Rodriguez-Clare, David Scharfstein, Robert Vishny, and participants in the Junior Faculty lunch group at the University of Chicago, the Finance seminar at UCLA, and the NBER Summer Institute for useful comments. Jayanta Sen and Alfred Shang provided excellent research assistance. A preliminary study was supported by the World Bank. We gratefully acknowledge financial support from NSF grant \#SBR-9423645. This paper is part of NBER's research programs in Corporate Finance and Economic Fluctuations and Growth. Any opinions expressed are those of the authors and not those of the National Bureau of Economic Research.

(C) 1996 by Raghuram G. Rajan and Luigi Zingales. All rights reserved. Short sections of text, not to exceed two paragraphs, may be quoted without explicit permission provided that full credit, including $(\mathcal{C}$ notice, is given to the source. 


\title{
FINANCIAL DEPENDENCE AND GROWTH
}

\begin{abstract}
Does finance affect economic growth? A number of studies have identified a positive correlation between the level of development of a country's financial sector and the rate of growth of its per capita income. As has been noted elsewhere, the observed correlation does not necessarily imply a causal relationship. This paper examines whether financial development facilitates economic growth by scrutinizing one rationale for such a relationship; that financial development reduces the costs of external finance to firms. Specifically, we ask whether industrial sectors that are relatively more in need of external finance develop disproportionately faster in countries with more developed financial markets. We find this to be true in a large sample of countries over the 1980s. We show this result is unlikely to be driven by omitted variables, outliers, or reverse causality,

\section{Raghuram G. Rajan}

Kellogg Graduate School of Management Northwestern University

2001 Sheridan Road

Evanston, IL 60208

and NBER

fac_rajan@gsbvax.uchicago.edu

Luigi Zingales

Graduate School of Business

University of Chicago

1101 East 58th Street

Chicago, IL 60657

and NBER

luigi@gsblgz.uchicago.edu
\end{abstract}


There is a large literature - dating at least as far back as Schumpeter (1911) - that emphasizes the links between the state of development of a country's financial sector and the level and the rate of growth of its per capita income. The argument essentially is that the services the financial sector provides - of reallocating capital to the highest value use without substantial risk of loss through moral hazard, adverse selection, or transactions costs - are an essential catalyst of economic growth. The existence of a correlation between financial development and economic growth has been documented in a number of empirical studies starting with Cameron (1967), Goldsmith (1969) and McKinnon (1973). Economic historians have identified spurts of growth in certain countries with the development of specific financial institutions. For example, Cameron (1961) and Gerschenkron (1962) have associated the economic growth of France in the middle of the nineteenth century with the establishment of the Credit Mobilier. ${ }^{1}$ Nevertheless, some economists have questioned the interpretation of these studies, arguing that correlation does not imply causality. Paraphrasing North, financial development does not cause economic growth, it is economic growth. ${ }^{2}$

In an important recent paper, Levine and King (1993a) investigate the causality problem following a post hoc, ergo propter hoc approach. They show that the predetermined component of financial development is a good predictor of growth over the next 10 to 30 years. While their paper does suggest that the observed correlation is not spurious, it does not lay to rest all doubts about causality. The sceptic could still offer a number of arguments.

First, both financial development and growth could be driven by a common omitted variable such as the propensity of households in the economy to save. Since endogenous savings (in certain macroeconomic models) affects the long run growth rate of the economy, it may not be surprising that growth and initial financial development are correlated. This argument is also hard to refute with simple cross-country regressions. In the absence of a well accepted theory

\footnotetext{
${ }^{1}$ Adopting a different tack, Kindleberger (1993) discusses the importance of finance to the outcome of wars (for instance, Britain's ability to mobilize financial resources after the Glorious Revolution of 1688 may explain why, with one-third France's manpower, it could defeat the French) and asks "Can Finance be relevant to military outcomes, as widely insisted on, but not to the course of economic development?"

${ }^{2}$ The early studies have typically been cautious about their findings. For instance, Goldsmith (1969, p48) writes "In most countries, a rough parallelism can be observed between economic and financial development if periods of several decades are considered. There is no possibility, however, of establishing with confidence the direction of the causal mechanism, i.e., of deciding whether financial factors were responsible for the acceleration of economic development or whether financial development reflected economic growth whose mainsprings must be sought elsewhere."
} 
of growth, the list of potential omitted variables that financial sector development might be a proxy for is large, and the explanatory variables to include a matter of conjecture (on this see Paxson, 1996).

Second, there is a potential problem of anticipation. Financial development - typically measured by the level of credit and the size of the stock market (but see King and Levine (1993a) for other proxies) - may predict economic growth simply because financial markets anticipate future growth; the stock market capitalizes the present value of growth opportunities, while financial institutions lend more if they think sectors will grow. Thus financial development may simply be a leading indicator rather than a causal factor.

To interpret these correlations in a more causal sense it is necessary to identify the mechanism through which financial development affects economic growth and to document its working. Our paper is an attempt to do this.

The fundamental role played by the financial sector is to facilitate the reallocation of funds from agents (individuals) with an excess of capital given their investment opportunities towards agents (firms) with a shortage of funds vis à vis their investment opportunities. This implies that financial development has two effects. First, by reducing the transactions costs of saving and investing, it lowers the overall cost of capital in the economy in general. Second, to the extent that financial markets and institutions help firms overcome problems of moral hazard and adverse selection, it should reduce the costs of external finance vis à vis the cost of internal funds such as cashflows.

Financial development, thus, should reduce both the cost of capital and the differential cost of external finance. Our paper focuses on the second effect. If the financial sector works through the cost of external finance, firms that are typically short of funds given investment opportunities should do better in economies with well developed financial sectors. The test then is whether firms (or industries) dependent on external finance for their growth are relatively "better off" in economies with well developed financial markets. A finding that they are could be the 'smoking gun' in the debate about causality. There are two virtues to this simple test. First, it focuses on the details of a mechanism by which finance affects growth, thus providing a stronger test of causality. Second, it can correct for fixed country (and industry) effects. Though its value depends on how reasonable our micro-economic assumptions are, it is less dependent 
on a specific macroeconomic model of growth.

Specifically, we propose the following test. We identify an industry's need for external finance (the difference between investments and internal cash generated from operations) from data on U.S. firms. Under the assumption that capital markets in the United States, especially for the large listed firms we analyze, are relatively frictionless, this method allows us to identify an industry's technological demand for external financing. We then examine whether the industries that are more dependent on external financing grow relatively faster in countries that initially have better developed financial markets and institutions.

We find evidence consistent with this. In a country which is one standard deviation above the mean of financial development, the difference in growth rates between an industry whose financial dependence is one standard deviation above the mean and the average industry, is $1 \%$ more (annually, and in real terms) than in the average country. Moreover, we find that industries that generate substantial cash flow from operations grow relatively faster in countries with underdeveloped financial systems. The intensity of investment in industries dependent on external finance is disproportionately higher in countries with more developed financial markets. Finally, firms in financially dependent industries are disproportionately larger in countries with more developed financial markets. Our results are robust to the introduction of various proxies for a country's level of development and human capital, making it unlikely that they are driven by an omitted variable.

Let us be careful about what we find, and about what we have little to say. Our findings suggest that the ex ante development of financial markets facilitates the ex post growth of sectors dependent on external finance. This implies that the link between financial development and growth identified elsewhere may stem, at least in part, from a channel identified by the theory: financial markets and institutions reduce the cost of external finance for firms. Of course, our analysis suggests only that financial development liberates firms from the drudgery of generating funds internally. It is ultimately the availability of profitable investment opportunities that drives growth, and we have little to say about where these come from.

Clearly, the plausibility of our work depends on how acceptable its underlying assumptions are. One of our assumptions is that there is a technological reason why some industries depend more on external finance than others. To the extent that the initial project scale, the 
gestation period, the cash harvest period, and the requirement for continuing investment differ substantially between industries, this is indeed plausible. More debatable is our assumption that these technological differences persist across countries despite vast differences in local conditions. However, all we really need is that statements of the following sort hold: If pharmaceuticals require a larger initial scale and have a higher gestation period before cashflows are harvested than the textile industry in the U.S., it also requires a larger initial scale and has a higher gestation period in Korea.

Furthermore, for a country's financial development to have any effect on industry growth in that country we have to assume that firms finance themselves largely in their own country. In other words, only if world capital markets are not perfectly integrated can domestic financial development affect a country's growth. There is a wealth of evidence documenting the existence of frictions in international capital markets: the extremely high correlation between a country's savings and its investments (Feldstein and Horioka, 1980), the strong home bias in portfolio investments (French and Poterba , 1991), and cross countries differences in expected returns (Bekaert and Harvey, 1995). We have little else to say about these two assumptions other than noting that their failure would weaken the power of our tests but not necessarily bias our findings.

Finally, we address concerns about the interpretation of our findings. As argued earlier, the size of financial markets might reflect the extent to which growth is capitalized. But this would not explain why there is a differential effect of financial development on the growth of industries dependent on external finance, nor why financial development continues to matter even when we use other proxies for it such as a country's accounting standards. A second possibility is that financial markets might develop in anticipation of the financing needs of industry. We regard this as unlikely for a number of reasons. It is not clear that the state of development of markets is the outcome of a rational plan. In many former colonies, it is determined by the identity of the colonial power and the legal and political systems they imposed (see La Porta, Lopez de Silanes, Shleifer and Vishny (1996)). ${ }^{3}$ At best, markets appear to develop in response to the

\footnotetext{
${ }^{3}$ For instance, India which has a common-law system introduced by the British has had a vibrant stock exchange since the last century (La Porta et al. argue that common law systems are more conducive to the development of equity markets). The stock exchange survived, albeit in a low energy state, even when many of the activities requiring external finance such as infrastructure development were taken over by the government
} 
current (and past) needs of industry (see Chandler (1977)'s discussion of the development of public corporate debt markets in the United States in response to the financing needs of the railroads) rather than anticipated needs.

But this suggests another explanation of our results. Perhaps, some factor may have been responsible for the past growth of financially dependent sectors. This, in turn, would explain the current development of financial markets, and the persistence of the factor would explain the growth of financially dependent sectors. Thus the current development of financial markets would be correlated with the growth of financially dependent sectors, even absent any of the channels we have discussed. Indeed we find that a country's financial development is strongly correlated with the ex ante proportion of financially dependent industries in that economy. Nevertheless, we still find that the relative growth rate of financially dependent industries is higher in more financially developed countries even when we restrict our analysis to sectors that are small at the beginning of the period, and hence unlikely to be responsible for the state of development of the financial markets. ${ }^{4}$ Furthermore, the basic correlation persists when we instrument with more exogenous measures of the state of development of capital markets such as a country's accounting standards, and when we include the interaction between an industry's financial dependence and the ex ante proportion of financially dependent industries in the economy (which is a proxy for the omitted factor).

While our interest is primarily in the macro-economic link between financial development and growth, there are at least two reasons why our work may also be of interest in the current microeconomic debate on whether firms are "credit rationed". First, much of the empirical literature on this issue has focused on large, publicly traded, U.S. (or Japanese) companies. The difference in liquidity constraints between such firms is likely to be small relative to the differences between industries across different financial markets which is our focus. Second, following the influential work by Fazzari, Hubbard and Petersen (1988), the papers in this literature have typically sorted firms on some ex ante proxy (such as the payment of dividends

after India got independence. With the gradual withdrawal of the government from industry in the 1980s, the stock market has resumed its role as an important source of finance for young firms.

${ }^{4}$ This is consistent with Chandler's account of the financing of U.S. industries. Their growth was partly driven by the availability of finance in a system that had largely been developed to fund infrastructure such as railroads and canals. 
or the existence of bank relationships) for financial constraints. They then argue that the higher sensitivity of investments to cashflows for firms that the ex ante proxy suggests are more susceptible to being constrained is evidence of a differential wedge between the cost of internal and external funds among these firms. A number of questions have been raised by this methodology. First, is the proxy really exogenous? Second, could cashflows proxy for investment opportunities, thus driving the correlation? Finally, as Kaplan and Zingales (1996) point out, the validity of such an approach depends on the monotonicity of the investment-cash flow sensitivity to the proxy for financial constraints, which - they show - does not necessarily hold. By contrast, they argue that a more appropriate test of the effects of financial constraints consists in analyzing the differential level of investments (and, thus, growth) across firms facing a differential wedge between the cost of internal and external funds.

The approach taken by our paper may deal with this criticism and suggest a new way of investigating these issues. For instance, financial development may be thought of as more exogenous to a particular industry than its dividend policy or its banking relationships (we do not imply that none of the proxies in the literature are exogenous). Furthermore, even if cashflows proxy for investment opportunities, it is the interaction with financial development that is evidence of financial constraints. Finally, our paper addresses the Kaplan-Zingales critique by testing for differences in industry growth across countries with differentially developed financial markets and, thus, with a differential wedge between cost of external and internal funds. So our evidence could be thought of as reaffirming that financial constraints do affect investment, while finessing the debate surrounding the previous work.

Finally, Demirguc-Kunt and Maksimovic (1996) also use micro data to develop a test of the influence of financial development on growth. Using firm-level data, they estimate the proportion of firms whose rate of growth exceeds the growth that could have been supported only by internal resources. They then run a cross country regression and find that this proportion is positively related to the stock market turnover and to a measure of law enforcement. While their paper is similar in spirit to ours, there are two essential differences. First, their estimate of the internal growth rate of a firm is dependent on the firm's characteristics. While it is potentially more accurate than our measure of external dependence, it is also more endogenous. Another difference is that in the spirit of traditional cross-country regressions, they focus on 
between-country differences, while our focus is on within-country, between-industry differences. The latter is an important innovation in this paper.

The rest of the paper is as follows. We describe our measure of financial dependency in section 1 . In section 2, we present our data on financial development, country characteristics, and industry growth. In section 3 we set up our main tests, we discuss the results in section 4 , and explore the robustness of our findings in section 5 . Section 6 concludes.

\section{A Measure of External Dependency}

If the presence of a well developed financial market reduces the costs of external finance, it must have a greater effect on the growth rate of firms that are more dependent on external funds. To investigate this, we have to determine a firm's demand for external finance over a certain period. Our earliest comprehensive measure of financial market development is for the year 1980, and our last systematic data on growth is for 1990. This then defines the period of interest to be 1980-1990.

We immediately face some problems. First, a problem of data availability; the most disaggregated comprehensive data we have for countries is at the industry level (data at the firm level, if available, is typically limited to large listed firms). Data on the actual use of external financing is typically not available. But even if it were, it would not be useable because it would reflect the equilibrium between the demand for external funds and its supply. Since the latter is precisely what we are attempting to test for, this information is contaminated. A second problem is that we are not aware of any systematic study of the external financing needs of different industries, either cross-sectionally or over time. Empirical work in corporate finance typically focuses on the choice between debt and equity, and not on the use of external versus internal funds. ${ }^{5}$

We, therefore, start by studying the external financing needs of U.S. companies over the 1980s. We use data from Compustat for this. Compustat does not contain a representative sample of U.S. firms, because is limited to publicly traded firms, which are relatively large. Nevertheless, we regard this as an advantage for two reasons. First, in a perfect capital market

\footnotetext{
${ }^{5}$ Mayer (1990) and Demirguc-Kunt and Maksimovic (1996) are exceptions. Mayer uses country level data.
} 
the supply of funds to firms is perfectly elastic at the proper risk adjusted rate. In such a market the actual amount of external funds raised by a firm equals its desired amount. In other words, in such an idealized setting, the identification problem does not exist. But capital markets in the United States are among the most advanced in the world, and large publicly traded firms typically face the least frictions in accessing finance. Thus the amount of external finance used by large firms in the United States is likely to be a relatively pure measure of their demand for external finance. Note that we are not assuming that the U.S. financial markets are perfect, but only that they are among the least imperfect.

A second reason for using a database on listed firms is that disclosure requirements imply that the data on financing are comprehensive. In the rest of the paper, we will take the amount of external finance used by U.S. firms in an industry as a proxy for the desired amount foreign firms in the same industry would have liked to raise had their financial markets been more developed.

Next, we have to define precisely what we mean by external and internal finance. We are interested in the amount of desired investment that cannot be financed through internal sources, i.e., the cash flow generated by the same business. Therefore, a firm's dependence on external finance is defined as the ratio of capital expenditures (Compustat \# 128) minus cash flow from operations divided by capital expenditures. Cash flow from operations is broadly defined as the sum of Compustat cash flow from operations (Compustat \# 110) plus decreases in inventories, decreases in receivables, and increases in payables. ${ }^{6}$ Note that this definition includes changes in the non-financial components of net working capital as part of funds from operations. In fact, in certain businesses these represent major sources (or uses) of funds, that help a firm avoid (or force it to tap) external sources of funds. ${ }^{7}$

Similarly, the dependence on external equity finance is defined as the ratio of the net amount of equity issues (Compustat \# 108 minus \# 115) to capital expenditures. Finally, the investment

\footnotetext{
${ }^{6}$ This item is only defined for cash flow statements with format codes 1,2 , or 3 . For format code 7 we construct it as the sum of items \# 123, 125, 126, 106, 213, 217.

${ }^{7}$ It could be argued that inter-firm trade credit should be viewed as a component of external financing. It is unclear how much of trade credit is used to reduce transactions costs and how much is used for financing. Much trade credit is granted routinely and repaid promptly and typically, net trade credit for a firm (accounts receivable less payables) is small (see Petersen and Rajan (1996)). This may be why trade credit is typically treated as part of operations in capital budgeting exercises. We adhere to this tradition.
} 
intensity is the ratio of capital expenditure to net property plant and equipment (Compustat \# 8).

To make these measures comparable with the industry level data we have for other countries, we have to choose how to aggregate these ratios across companies and over time. For each firm, we sum the numerator and denominator over time before dividing. For instance, we sum the firm's use of external finance over the 1980s and then divide by the sum of capital expenditure over the 1980s to get the firm's dependence on external finance in the 1980s. This smooths temporal fluctuations and reduces the effects of outliers. To summarize ratios across firms, however, we use the industry median. We do this to prevent large firms from swamping the information from small firms; for instance, we know that IBM's free cash flow does not alleviate possible cash flow shortages of small computer firms.

Finally, we are concerned about the existence of a life cycle of financing - firms are more dependent on external financing early in their life than later - which is "common wisdom" in the corporate finance literature (though we were hard-pressed to find formal empirical studies of this phenomenon).

Figure 1 shows such common wisdom to be true. It plots the median financing and investment needs across U.S. firms as a function of the number of years since the initial public offering (IPO). Not surprisingly, in the year of the IPO, firms raise a substantial amount of external funds (especially equity). More interestingly, this continues - albeit on a smaller scale - up to approximately the 10th year. After that period, net equity issues go to zero and the usage of external finance fluctuates around zero. Although this pattern appears to be fairly standard across different industries, the level of external financing, both at an early stage and at a later stage is quite different across industries. For example, in figure 2, we report the pattern of investment and financing in two different industries. Companies in the computer industry show an intensive use of external funds in the first decade of their existence, with occasional spurts of external and equity financing later on. By contrast, external finance goes to zero very shortly after the IPO in the steel industry, but further substantial needs of external (and equity finance) might arise later in life of a company.

In Table 1, we look at these differences more systematically. We tabulate by International Standard Classification Code (ISIC) the median fraction of investments U.S. firms financed 
externally (column I) and financed with equity (column II) during the 1980s. To highlight the need for investments, in column III we also report the level of capital expenditures divided by net property plant and equipment. We restrict our attention to those manufacturing industries for which we have value-added data from the United Nations Statistics. We report these figures for all firms, mature firms (firms that did an IPO at least 10 years ago), and young firms (firms that went public in the last 9 years). Not surprisingly, among mature firms, radio and computers emerge as the two industries with the largest need for external finance, while tobacco is the industry with the largest excess amount of internal funds relative to capital expenditures. This is also reflected in its large equity repurchases. The clustering of external financing in a few sectors is even more pronounced among young firms.

Given that the life-cycle pattern of external financing differs by industry, the most appropriate measure of external financing needs in other countries is debatable. The financing needs of mature companies represent a better proxy for the financing needs of existing firms in other countries. However, young firms may make up a larger fraction of the industry, especially in developing countries, than they do in the United States. In the absence of more data on industry composition, we will use the median across all firms in the industry in the U.S. to measure dependence. However, we will examine if the result is sensitive to using just young or old firms.

\subsection{Is the Financial Dependence of U.S. Firms a Good Proxy?}

Much of our analysis rests on financial dependence of U.S. firms being a good proxy for the demand for external funds in other countries. We think this is reasonable for four reasons.

First, in a steady state equilibrium there will not be much need for external funds, as Figure 1 shows. Therefore, much of the demand for external funds is likely to arise as a result of technological shocks that raise an industry's investment opportunities beyond what internal funds can support. To the extent these shocks are worldwide, U.S. firms' need for funds represents a good proxy. 8

Second, even if the new investment opportunities generated by these worldwide shocks differ

\footnotetext{
${ }^{8}$ This amounts to saying that if the invention of personal computers increased the demand for external funds in the U.S. computer industry, it is likely to increase the need for funds in the computer industry in other countries as well.
} 
across countries, the amount of cash flow produced by existing firms in a certain industry is likely to be similar across countries. In fact, most of the determinants of ratio of cash flow to capital are likely to be similar worldwide: the level of demand for a certain product, its stage in the life cycle, and its cash harvest period. For this reason, we make sure that our results hold even when we use the amount of internally generated cash, rather than the difference between investments and internally generated funds.

Third, one might argue that the stage of a product life cycle that U.S. firms are in is likely to be different from that of foreign firms. Given that our sample is biased toward developing countries one might think that the U.S. industry in the 1970 s might be a better proxy for developing countries' position in a product life cycle. For this reason, we also explore the robustness of our results to measuring the financial dependence of U.S. firms in the 1970s rather than in the 1980s.

Last but not least, that we only have a noisy measure of the need for funds creates a bias against finding any effect of financial development on growth.

\section{Data.}

\subsection{Data on financial development.}

We start by describing our data on financial development contained in Table 2. Ideally, we would like a measure of a firm's ability to raise money. This depends on the variety of intermediaries available, and the efficiency with which they perform the evaluation, monitoring, certification, communication and distribution functions. Since there is little agreement on how these are appropriately measured, and even less data available, we will have to make do with crude proxies even though they may miss many of the aspects we think vital to a modern financial system.

Turning first to equity markets, one measure of stock market development may be the amount of money raised through initial public offerings and secondary offerings. Unfortunately, this measure is not available on a systematic basis for many countries. Moreover, it is well documented in the U.S. (see earlier) that mature firms are reluctant to issue stock, even though they have the potential to do so. It could then be argued that stock market capitalization is a 
better measure of the availability of finance. Another virtue of this measure is that it is consistent with the traditional literature (see Goldsmith (1969) for example) which has typically used the ratio of the size of the financial sector to output as a measure of financial sector development. So the ratio of stock market capitalization to Gross Domestic Product in 1980 is the measure of stock market development that we use. We obtain stock market capitalization for all countries listed in the Emerging Stock Markets Factbook (which, interestingly, contains data on developed countries also) published by the International Finance Corporation. ${ }^{9}$

A comparable measure for the state of development of credit markets is the ratio of domestic credit to Gross Domestic Product, a measure also used by King and Levine (1993a). This is obtained from the International Financial Statistics (IFS) published by the International Monetary Fund. Specifically, this measure is the ratio of IFS lines 32a through 32f and excluding 32e. Finally, we also compute the fraction of credit allocated to the private sector, which is the ratio of claims on the non-financial private sector (IFS line 32d) to total domestic credit.

There are, of course, elements we do not capture. For instance, we do not have data on corporate bond markets for more than a handful of countries. Except for the United States which is not included in our tests, and Japan, corporate bond markets were typically small in the early 1980s (see Rajan and Zingales, 1995). A potentially more damaging omission is private equity and private placement of debt (not held by institutions). While they may be correlated with measures of financial market development, there are certain countries where they clearly are not. For instance, in Italy, most medium sized companies are privately held (see Pagano, Panetta, and Zingales, 1995) while the stock market is relatively small. The lack of this data may not be a serious problem because, after all, we are interested in how the availability of external funds affects firms; the amount of private equity outstanding is generally a reflection of the amount of internal finance privately held companies have secured in the past, and therefore is not a measure of how developed the financial markets are.

\footnotetext{
${ }^{9}$ Stock market capitalization is measured at the end of the year, while Gross Domestic Product may value flows through the year. This may be a problem in bigh inflation countries. We therefore measure GDP as the GDP in constant prices multiplied by the producer price index where the base year for both series is five years before the year of interest.
} 


\subsection{Data on countries.}

The Gross Domestic Product, the Producer Price Index, the exchange rate, and the Index of Industrial Production are all obtained from International Financial Statistics. Whenever a particular series is not available, we use close substitutes - for instance, the wholesale price index if the producer price index is not available. Data on a country's human capital (average years of schooling in population over 25) and the share of investment in GDP in 1980 are obtained from the Barro-Lee files downloaded from the NBER web site (see Barro and Lee (1994)).

\subsection{Data on industries.}

Data on value added and gross fixed capital formation for each industry in each country are obtained from the General Industrial Statistics (vol 1) database put together by the United Nations Statistics Division. We checked the data for inconsistencies, changes in classification of sectors, and changes in units. The U.N. data is classified by International SIC code. In order to obtain the amount of external finance used by the industry in the U.S., we matched ISIC codes with SIC codes. Typically, the three digit ISIC codes correspond to two digit SIC codes, while the four digit ISIC code corresponds to three digit SIC codes. In order to reduce the dependence on country specific factors like natural resources we confine our analysis to manufacturing firms (U.S. SIC 2000-3999). Table 3 presents summary statistics for all these variables.

We would like data on as many countries as possible. The binding constraint is the availability of comparable data on a country's equity markets. We started with 55 countries from the Emerging Stock Markets Factbook. We dropped countries like Kuwait that did not report a stock market capitalization till the latter half of the 1980s. We could not use Hong Kong and Taiwan because data on these countries are not present in the International Financial Statistics volumes. We also dropped countries for which we did not have data from the G.I.S. database that is separated by at least five years (notably, Switzerland). Finally, Thailand is dropped because the U.N. notes that data from year to year are not comparable. The United States is excluded from the analysis because it is our benchmark. This leaves us with the 43 countries in Table 2. 


\subsection{Data description.}

Our basic measure of financial market development - which we term "financial development" - is the sum of domestic credit and stock market capitalization to Gross Domestic Product. Table 2 lists this measure and its components for countries in our final sample. A number of patterns are discernible from an analysis of this table. First, credit markets are more developed in richer countries. The correlation of log per capita income in 1980 with financial development is 0.43 (significant at the $1 \%$ level) the correlation with the ratio of credit market to GDP is 0.45 (significant at the $1 \%$ level), while the correlation with equity market capitalization to GDP is 0.17 (though significant only at the $25 \%$ level). The weak correlation between stock markets and per capita income is consistent with La Porta et al.'s view that colonial influences and legal tradition, rather than economic conditions, are a strong determinant of the development of equity markets. As an example, Singapore and Malaysia (under British common law influence) have strong equity markets while Phillipines (under Spanish civil law) has weaker equity markets. Second, there seems to be no relationship (if anything, weak substitution) between the development of credit markets and the development of stock markets (correlation $=-0.08$, not significant), a fact previously noted by Demirguc-Kunt and Levine (1995). Third, the fraction of domestic credit going to the private sector is strongly correlated with market capitalization to GDP (correlation $=0.5$, significant at the $1 \%$ level). Possible explanations of this correlation are that government involvement in industry crowds out the private sector, that the government intervenes to fill the cap created by the absence of the market, or that respect and enforcement of private property rights drives both variables. Finally, the fraction of domestic credit going to the private sector is correlated with log per capita income (correlation $=0.27$, significant at the $10 \%$ level).

We want to see if financially dependent industries are likely to be better off in countries with well developed financial sectors. The availability of finance affects not just investment but also the ability to finance operations and sales through working capital. Therefore, the most appropriate measure of an industry being "better off" is the growth in value added for that industry, i.e., the change in the log of real value added in that industry between 1980 and 1990 . Real value added in 1990 is obtained by deflating value added by the Producer Price Index. For 
high inflation countries, spurious differences in value added may be obtained simply because the UN data are measured at a different point from the PPI index. So, instead, we determine the effective deflator by dividing the growth in nominal value added for the entire manufacturing sector in the UN database by the index of industrial production (which measures the real growth rate in industrial production) obtained from the IFS statistics.

The raw correlation between financial market development and the growth of the manufacturing sector across the 43 countries is 0.27 (significant at the $10 \%$ level). This is consistent with the results in King and Levine (1993a), who show that the predetermined component of market development affects future growth.

\section{Financial dependence and growth}

\subsection{The basic test}

Our hypothesis is that industries that are more dependent on external financing will have relatively higher growth rates in countries that have more developed financial markets. In other words, the explanatory variable whose influence we are interested in is the interaction between an industry's dependence on external finance (as measured in the U.S.) and local financial market development.

Our study, therefore, has one important advantage over recent cross-country empirical studies of growth (e.g., Barro (1991), Kormendi and Meguire (1985), King and Levine (1993a), Levine and Renelt (1992), Mankiw, Romer, and Weil (1992), and Demirguc-Kunt and Maksimovic (1996)). That advantage is simply that we make predictions about within country differences between industries based on an interaction between a country and industry characteristic. Therefore, we can correct for country and industry characteristics in ways that previous studies were unable to correct for, and will be less subject to criticism about an omitted variable bias or model specification.

The dependent variable is the average annual real growth rate of value added in industry $\mathrm{j}$ in country $\mathrm{k}$ over the period 1980-1990. ${ }^{10}$ The most effective way of correcting for country

\footnotetext{
${ }^{10}$ We exclude the United States in all subsequent regressions. As noted earlier, for some countries data availability limits the period even further. However, for no country do we have data separated by less than 5 years.
} 
and industry characteristics is to use indicator variables, one for each country and industry. The disadvantage of such a "fixed effects" regression is that the determinants of relative growth other than the interaction of interest become less transparent. So we start by including country characteristics and industry characteristics instead of indicator variables. The model we estimate is then

$$
\begin{gathered}
\text { Growth }_{j, k}=\beta_{1 . . m} \cdot \text { Country } \text { Characteristics }+\beta_{m+1 . . n} \cdot \text { Industry } \text { Characteristics } \\
\beta_{n+1 . . p} \cdot(\text { Characteristics of country and industry })+\beta_{p+1} \text { Interaction }+\epsilon
\end{gathered}
$$

Among the country characteristics we include are investment's share in GDP in 1980, log of per capita income in dollars in 1980, the average years of schooling in population over age 25 , and our measure of financial development (which is the sum of domestic credit and stock market capitalization to Gross Domestic Product).

The industry characteristic we include initially is industry $j$ 's dependence on external financing in the U.S. Finally, we include two variables that are characteristic of both country and industry; industry $j$ 's share in country $k$ of total value added in manufacturing in 1980 and the interaction between industry $\mathrm{j}$ 's dependence on external financing in the U.S. and financial market development in country $\mathrm{k}$. We will then drop the country specific and industry specific characteristics, and replace them with indicators for each country and each industry. This will be the basic regression in the rest of the paper.

\section{Results from the basic regression.}

As can be seen in Table 4, the coefficient estimate for the interaction term is positive and statistically significant at the $1 \%$ level (throughout the paper, the reported standard errors are heteroskedasticity corrected). The interaction term is akin to a second derivative. Using the

Dropping these countries does not qualitatively affect the results. We reduce the impact of outliers by constraining growth between -1 and +1 . Three observations are affected. The coefficient estimates for the interaction coefficient are higher and still significant when we do not do this, though the explanatory power of the regression is lower. We also rerun the same specification after winsorizing the $1 \%$ and $5 \%$ tails of the growth rate distribution obtaining virtually identical results (except that the explanatory power of the regression is still higher).

A potential concern is that we measure growth in value added rather than growth in output. Unfortunately, we do not have data for the latter. While we may not capture increases in productivity fully, we see no obvious way in which this should bias our results. 
estimates in the first column, in a country which is one standard deviation above the mean of financial development, the difference in growth rates between an industry whose financial dependence is one standard deviation above the mean and the average industry, is lin the average country. Is the effect large or small? Note that this measures the differential impact of financial development on financially dependent industries, rather than the overall relationship between financial development and growth. Still, the effect is of the same order of magnitude (see below) as the effect of variables such as investment's share of GDP and per capita income that populate cross-country growth regressions.

The other explanatory variables are also of interest. The following numbers in parentheses indicate the effect on industry growth of a one standard deviation increase in the explanatory variable. The higher investment's share of GDP in 1980, the higher an industry's growth rate (1.6\%). Developed countries have lower growth rates in manufacturing as evidenced by the negative coefficient on the log of per capita income (-2.5\%). The number of years of schooling has a small and insignificantly negative correlation with growth $(-0.3 \%)$, while industries in countries with more developed credit markets have a higher growth $(0.5 \%)$. Industries that have a considerable dependence on external finance have slower growth (-1\%) though this only borderline statistically significant at the $10 \%$ level, as do industries that account for a larger share of a country's manufacturing sector in $1980(-1.3 \%) .{ }^{11}$ Thus the explanatory variables have plausible effects.

Next, we include indicator variables for all the countries in the sample. As seen in Table 4, the coefficient estimates for the industry-specific and interaction variables are stable. The explanatory power of the regression goes up substantially, suggesting that much of the variation in growth rates is because of omitted inter-country differences. We re-estimate the regression now including indicators for the industries. The coefficients for country-specific and interaction variables are again surprisingly stable. Finally, we estimate the regression including indicators for all countries and industries. This is the basic regression we use in the rest of the paper, and the coefficient is positive $(\beta=0.069)$ and significant at the $1 \%$ level. It does not appear that one single country or industry is responsible for the results. The fundamental partial correlation

\footnotetext{
${ }^{11}$ A possible explanation for this coefficient estimate is measurement error. Those industries that are incorrectly measured to be small in the beginning of the decade will be seen to have grown faster.
} 
seems robust.

\subsection{Influence of composition of markets.}

Does the break-up of the capital market between equity and debt make a difference? Does it matter how much credit is channeled to the government sector and how much to the private sector?

Some theoretical studies have argued for a correlation between the existence of stock markets and growth and there is some evidence of this (King and Levine, 1993b). As Levine (1991) argues, capital raised through equity issues is long term (for the firm), while shares can be liquidated by the investor at short notice without impacting the firm's projects. By contrast, if the firm finances with non-tradeable, finite maturity debt held by institutions, shocks to the institutions may be transmitted on to the firm and force liquidation of long term projects. To the extent that stock markets create a separation between the liquidity shocks of investors and the investment needs of firms, the latter can take a longer term view and invest more efficiently. Growth should be higher if equity markets account for a larger proportion of credit markets. An alternative view is that managers who are constantly evaluated by the stock market tend to take the short term view (see Stein (1989) for a theory) and therefore it is better that they obtain finance for long term projects from financial institutions. We do not have the space here to review all the arguments in the theoretical literature on the relative merits of markets and institutions (see Aoki and Patrick (1994) for an extensive discussion). It suffices to say that the predictions are ambiguous.

Since the relative merits are an empirical matter, we compute the ratio of equity market capitalization to GDP. We then include the interaction between this ratio and the industry's dependence on external finance in the basic regression (see Table 5). We find that a dollar of market capitalization is not the same as a dollar of credit; it has only $40 \%$ of the effect on the growth of financially dependent firms. Unfortunately, this finding that market capitalization has less effect than credit cannot be as easily interpreted as if it were the reverse finding. The reason we must be cautious about interpreting this to mean that institutions are "better" than markets in channeling funds to financially dependent firms is because, unlike a dollar of credit, a dollar of market capitalization does not necessarily mean that some firm obtained a dollar 
of finance. The lower effect of market capitalization may simply reflect the translation ratio between market capitalization and eventual finance through new share issues. ${ }^{12}$

While this test does not give unambiguous results, it suggests a further way of testing whether the form of finance matters. We test whether, correcting for the other effects, industries that are equity dependent thrive better in a country with a greater relative size of the stock market. We therefore include the ratio of equity to total external finance used by U.S. firms in the same industry interacted with the ratio of market capitalization to size of capital markets. If the form of finance matters, the coefficient of this term should be positive. It turns out to be negative and insignificantly different from zero.

Put together, the tests suggest that equity markets do not have disproportionately beneficial effects on the relative growth rate of financially dependent firms. Nevertheless, equity markets are positively correlated with growth. When we re-estimate equation (1) without the interaction term but with the market capitalization to GDP included, we find a positive (though insignifjcant) relationship between market capitalization and growth, over and above its contribution to the included significant measure of financial market development. In summary; our results suggest growth may be positively correlated with the size of equity markets for reasons that are unrelated to the availability of external finance. For example, the better risk sharing effected through equity markets may reduce the cost of capital to all firms, not just the financially dependent ones. This would imply higher growth rates for countries with well developed stock markets but not necessarily differences in growth rates between its industries.

The effect of channelling funds to the public sector rather than the private sector is captured in Table 5 by including the interaction between an industry's need for external funding and the

\footnotetext{
${ }^{12}$ We use countries only in the Emerging Markets Factbook because otherwise we do not know the size of the stock market. There is, however, a potential selection problem of look-back bias in these countries. The IFC may only include countries that, ex post (i.e., in the latter half of the 1980s when the database was initiated), have a reasonably sized stock market. This selection bias does not appear severe because the data set seems to contain every country (we know of) that had a stock market at the beginning of the 1980s. Moreover, some of the stock markets present in the dataset are miniscule in the late $1980 \mathrm{~s}$, suggesting that this may not have been an important criterion. Nevertheless, ,we can think about the consequences of a potential selection bias. The bias would be most important in the case of countries with small stock markets in 1980, that based on the hypothesized selection criterion, would have grown the fastest. This would induce a negative correlation between the size of the stock market and growth. While such a correlation is not borne out in the data, and the selection bias does not directly predict any correlation for the interaction term, this suggests further caution about comparing the coefficients of credit and equity market capitalization.
} 
ratio of domestic credit to the public sector to GDP. The coefficient is large and strongly negative (coefficient estimate $=-0.16, t=-3.3$ )). This implies that the overall impact of a dollar of extra credit, if directed at the public sector, is to reduce the relative growth rate of financially dependent industries by about half as much as a dollar of credit to the private sector increases it. This evidence can be interpreted in a number of ways. It may indicate that public sector credit is not directed at financially dependent segments, and perhaps is misallocated to those segments that do not need it. Alternatively, it may be that involvement by the deep pocket government has a disproportionate crowding out effect on the private sector (and thus reduces growth) in industries that are financially dependent.

\subsection{Decomposition of the sources of growth.}

An industry can grow because new firms are added to the industry and because existing firms grow in size. Does the interaction term affect only one of these or both? The U.N. database also reports the number of firms in an industry. This statistic may often be compiled by a different body in a country from the one that produces the value-added data. The advantage is that it provides an independent check on our results. The disadvantage is that the industry classification used by the body compiling the number of firms may differ from the industry classification used by the body compiling value-added data, resulting in an increase in noise.

The growth in the number of firms is the difference in the log of ending period firms less the $\log$ of firms in the beginning of period. The average size of firms in the industry is obtained by dividing the value added in the industry by the number of firms, and the growth in average size is obtained again as a difference in logs. We then estimate the basic regression with growth in number of firms and growth in average size as dependent variables. The coefficient (not reported in table) of the interaction term is almost equal in both cases $\left(\beta_{\text {number }}=.022, \beta_{\text {avg size }}=.023\right)$, while the coefficient in the numbers regression is estimated more precisely $\left(t_{n u m b e r}=2.06\right.$, $t_{\text {avg size }}=1.73$ ). The coefficient estimates suggest that the incremental growth of financially dependent firms in more developed markets is almost equally driven by a growth in the number of firms and by a growth in average size.

If the development of financial markets affects both the growth in the number of firms in financially dependent industries and their average size, it must be that the average size of firms 
in financially dependent industries is larger in economies with developed markets. This is indeed the case. When we estimate the basic regression with the log of the average size of firms in an industry in a country at the end of the 1980s as the dependent variable (estimates not reported), the coefficient of the interaction term is positive and highly significant. It remains so when the dependent variable is the average size at the beginning of the 1980s. So the scale of firms is related to the development of financial markets.

\section{Robustness}

There are obviously many differences between the same industry in different countries. That we find such a strong interaction effect between an industry's financial dependence and the country's financial development is surprising. We, therefore, perform a number of robustness checks to rule out more mechanical explanations. First, we check if the correlation is sensitive to redefining financial dependence as the dependence of young firms or old firms, or measuring dependence in the 1970s rather than the 1980s. If the correlation is not robust to these changes in definition of dependence, it makes us less confidant in the universality of our measure of dependence.

\subsection{Is the correlation robust to changes in the measure of financial depen- dence?}

We calculate financial dependence restricting the sample only to mature firms (listed for more than 10 years) in the United States. The coefficient estimated for the interaction term, 0.05 , is statistically significant (see Table 6, column (I)). When we estimate the regression with dependence defined as the dependence of young firms in the United States on external finance, the coefficient on the interaction term is similar (0.04) and still statistically significant, though only at the $10 \%$ level (see Table 6 , column (II)).

Next, we check whether there is persistence in the pattern. If the pattern of financing in the United States in the 1980s is very different from the pattern in the 1970s, it would be unreasonable to expect it to carry any information for other countries (especially developing countries that may use older technologies). Furthermore, such a check would alleviate concerns 
that aberrations in a few industries in the 1980s drive the results.

The raw correlation between an industry's demand for external financing in the 1980s and its demand in the $1970 \mathrm{~s}$ is 0.63 . When we include the demand for external financing in the 1970s in the basic regression instead of demand in the 1980s, the coefficient is positive and statistically significant (see Table 6, column (III)). The coefficient is about $40 \%$ larger than that estimated for the 1980s. Though it is measured less precisely, it is still statistically significant at the $5 \%$ level. ${ }^{13}$

\subsection{Is the correlation robust to changes in the measure of financial develop- ment?}

As a measure of the development (and thus efficiency) of capital markets we have used the sum of domestic credit and equity market capitalization to measure financial development. Although crude, this is the most common measure used in prior studies and captures fairly well our priors. There are, however, some aberrations (see Table 2). For instance, Malaysia has a very high level of financial development, driven largely by its strong equity markets, while Belgium has a lower level of development, because its equity market is minuscule. La Porta et al. (1996) attribute this to differences in legal systems that emerged as a result of foreign invasions and colonial domination. The Malaysian legal system was influenced by British common law (which promotes equity markets), while the French civil code (which does not) was imposed on Belgium by Napoleon. Rather than being a source of concern, the "aberrations" are a source of strength for the study because they enable us to tell the effect of financial development apart from economic development. ${ }^{14}$

The proxy for financial development we would really like to have is a direct measure of the efficiency of capital markets. While the combined size of the credit and equity market is likely to be highly correlated with this, it is incumbent on us to see that the effect we measure is robust to changes in this measure. An alternative way to measure the degree of sophistication and

\footnotetext{
${ }^{13}$ The statistical significance of the coefficients for all the models in this subsection tends to increase substantially when the dependent variable is trimmed at the $1 \%$ and $5 \%$ levels.

${ }^{14}$ We do check, however, that our results are not driven by "strange" outliers. In particular, the results are unchanged if we drop Jordan, which scores surprisingly high on our measure of financial development, from the regression.
} 
efficiency of a capital market is to look at its accounting standards. The Center for International Financial Analysis and Research creates an index for different countries by rating the annual reports of at least three firms in every country on the inclusion or omission of 90 items. Thus each country obtains a score out of 90 with a higher number indicating more disclosure. The greater the public information, the lower should be the cost of external finance relative to internal finance. So this should be a proxy for financial development. ${ }^{15}$ While more developed countries have better accounting standards (see Laporta, et al.), there are exceptions. For instance, Malaysia scores as high as the United States, Australia or Canada on this measure, while Belgium and Germany are in the same league as Korea, Phillipines, or Mexico. The correlation between our capitalization measure of financial development and accounting standards is 0.39 (significant at the $5 \%$ level for the 32 countries for which we have this data). When we include the interaction between financial dependence and accounting standards instead of our previous measure of financial development (see Table 6, column (IV)), the coefficient is positive and highly statistically significant $(\beta=0.16, t=4.35)$.

With more confidence in our measures of financial dependence and financial development, we now turn to other concerns.

\subsection{Focussing on substantial industries}

It may be argued that differences in other sources of comparative advantage may dictate the presence, absence, or growth of industries in a country. Even if this is the case, our results cannot be explained unless the dependence of industries on this source of comparative advantage is strongly correlated with their dependence on external funding and financial development is a good proxy for the source of comparative advantage. As an example, the availability of natural resources may drive the growth of the mining sector. If mining is dependent on external finance, and if resource intensive countries developed financial markets (either by chance, by common colonial heritage, or by design) then the presence or absence of natural resources would drive the correlation.

\footnotetext{
${ }^{15}$ Unfortunately, we do not have this measure for all the countries in our sample. Also the Center for International Financial Analysis and Research which produces this data was set up only in 1984. So we do not have a measure of the accounting standards at the beginning of the period. This may not be a big problem because the standards do not change dramatically in a short period.
} 
In the ideal thought experiment, we should focus on industries like cement that are present in almost every country and do not require special technology, human capital, or natural resources (but do require finance). We do not have data in such detail, nor are there enough such industries to give us the cross-sectional variation to enable us to estimate our coefficients (even if the data were available). Nevertheless, we can attempt to minimize the problem, as well as see if it is a source of concern.

By restricting the sample to manufacturing firms, we have already reduced the influence of availability of natural resources. Also, if an industry has a substantial presence in a particular country, it is logical that country has the necessary resources and talents for the industry. So by further restricting the sample to industries that are above the median size in the country in 1980 , we reduce the problem of differences in growth stemming from differences in endowment. When we estimate the regression with this smaller sample (Table 6, column (V)), the interaction variable is still positive and statistically significant $(\beta=0.06, t=2.65)$.

We can also test if either financial dependence or financial development proxy for something else. Industries that are highly dependent on external finance - for example, drugs and pharmaceuticals - may also be highly dependent on human capital inputs. To the extent that financial market development and human capital are correlated, the observed interaction between financial dependence and financial development may proxy for the interaction between human capital dependence and the availability of trained human capital. To check this, we include in the basic regression an interaction between the industry's dependence on external finance and the measure of the country's stock of human capital (average years of schooling in population over age 25). As the coefficient estimates in Table 7, column I show, the coefficient on the human capital interaction term is small and not statistically significant, while our fundamental interaction term is virtually unchanged. This suggests that financial dependence is not a proxy for the industry's dependence on human capital.

Another possibility is that a lower dependence on external financing in the United States simply reflects the greater maturity of the industry. An influential view of the development process is that as technologies mature, industries using those technologies migrate from developed economies to developing economies (see, for example, Dornbusch, Fischer, and Samuelson (1977)). Since developing countries are more likely to have underdeveloped financial markets, 
the interaction effect we document may simply reflect the stronger growth of mature technologies in underdeveloped countries.

We already have results suggesting this cannot be the entire explanation. The interaction effect is present even when dependence is measured only for young firms in the United States. Financial dependence is unlikely to proxy for technological maturity for these firms.

Furthermore, we can test if financial development is really a proxy for economic development in the regression. We include in the basic regression the interaction between the industry's dependence on external finance and the log per capita GDP for the country, in addition to our usual interaction term. As seen in Table 7, column (II), the coefficient of the interaction term falls to 0.05 (from 0.07 in the basic regression) but is still statistically significant. The interaction between financial dependence and log per capita income is positive and borderline statistically significant at the $10 \%$ level. This may be because log per capita income captures some aspects of financial development that are not captured by our proxy. Of course, we cannot rule out the possibility that financial development is a better proxy for economic development than log per capita income. Nevertheless, taken together, the above tests do not offer strong support for financial dependence being a proxy for technological maturity.

\subsection{Other explanations: Reverse Causality.}

Thus far, we have taken the state of financial markets as predetermined and exogenous. An alternative explanation of the development of financial markets is that they arise to accommodate the financing needs of finance-hungry industries.

The argument is as follows. Suppose there are some underlying country specific factors that favor certain industries that happen to be finance hungry. Then, countries abundant in these factors should experience higher growth rates in financially dependent industries and - as a result - should develop a strong financial market. If these factors persist, then growth rates in financially dependent sectors will persist and we will observe the significant interaction effect. But here it will result from omitted factors than any beneficial effect of finance.

The lack of persistence in country growth over periods of decades (see Easterly, Kremer, Pritchett, and Summers (1993)) and the low correlation of sectoral growth across decades (Klenow, 1995) suggest that this should not be a major concern. Nevertheless, we can in- 
vestigate the reverse causality argument more directly.

We construct a measure of the average financial dependence of a country's industrial structure in 1980; we weight the dependence on external financing for an industry by its relative contribution to value added in the manufacturing sector, and sum across industries in the country. This gives us a measure of the proportion of financially dependent firms in that country. When we sort countries on this measure, less developed economies like Sri Lanka and Indonesia are low on this measure while developed economies like Netherlands, Japan and the U.K. are high on this list. But there are exceptions. Singapore, Israel and Malaysia are high on the list while Portugal, Greece, and Belgium are below the median.

A regression with a country's financial development in 1980 as the dependent variable and the weighted average financial dependence of its industries in 1980 as the explanatory variable results in a strong positive coefficient $(\beta=2.89, \mathrm{t}=2.51, \mathrm{R}$ square $=0.19)$. Interestingly, the correlation is not statistically significant at conventional levels when dependence is measured for young firms. A possible explanation is that it is the older (and larger) firms that largely determine the size of the financial sector. A similarly strong correlation is observed when we regress market capitalization against weighted average equity dependence. On the one hand, this lends credence to our method of extrapolating the financial dependence of industries in the United States to other countries - as might seem natural, financial markets and institutions develop to meet the needs of financially dependent industries. On the other hand, this finding suggests reverse causality may indeed be an issue.

If an omitted factor explains both the growth of industries and the development of financial markets, its influence should be especially felt for large industries in economies where the ex ante weighted average financial dependence is high. These industries would be largely responsible for the state of financial markets and their size is presumably driven by an abundance of the omitted factor. We include an indicator (multiplied by the standard interaction term) if an industry is above median size and is in an economy with above median weighted average financial dependence. If a persistent omitted factor is responsible for financially dependent industries having become large, and also consequently for the size of the financial markets, the coefficient of this term should be positive (and absorb a lot of the interaction term). In fact, the coefficient is negative, though not significant (see Table 7, column (III)). The coefficient of the standard 
interaction term is unchanged.

Again, if an omitted factor drives our results, the introduction of an interaction between a proxy for the omitted factor and financial dependence should weaken the coefficient estimate for our fundamental interaction. Although we cannot measure this factor directly, we can obtain a proxy for it. Under the alternative explanation of reverse causality, it is this unobserved factor that is responsible for the large past growth of financially dependent industries and, thus, for the development of the financial sector. As a result, the beginning-of-period relative importance of financially dependent sectors in each country can be used as a proxy for such an omitted factor. We re-estimate, then, the basic specification after inserting as a regressor the product between a country's weighted average external dependence and an industry's financial dependence (see Table 7, column (V)). The estimated coefficient of the interaction between financial dependence and financial development is virtually unchanged (even slightly increased).

The two findings above - that the state of development of an economy's financial sector is explained by the relative weight of industries dependent on external finance and that the fundamental interaction does not simply reflect the continued growth of financially dependent industries that, in the past, were responsible for the development of the financial sector - are not in contradiction. Taken together, they suggest the possibility that financial markets and institutions may develop to meet the needs of one set of industries, but then facilitate the growth of another smaller, younger, group of industries.

To investigate this, we estimate the effect of financial development only for industries that are small to start out with, and are unlikely to be responsible for the state of development of the financial markets. So we estimate the basic regression for industries that in 1980 were less than the median size in their respective countries. The coefficient of the interaction term is positive and significant (see Table 7, column (IV)) even for these industries, for whom the economy's financial development is largely predetermined.

Finally, to address the reverse causality argument we re-estimate the basic specification by using instrumental variables. The proper instruments are variables likely to affect the development of financial markets, but not to be affected by it. For this reason we resort to institutional variables. While some legal traditions may foster the development of capital markets, it is unlikely that the relationship runs in the opposite direction. La Porta et al. (1996) suggest that 
the origin of a country's legal system has an effect on the development of a domestic capital market. Similarly, the efficiency and the integrity of the legal system are a precondition for a sophisticated capital market, but the reverse is unlikely to be true. Therefore, we use the country of origin of the legal system as classified by La Porta et al. (1996) and an index of the efficiency of the judicial system produced by Business International Corporation (a country-risk rating agency) as instruments for financial development. As Table 7, column (VI), shows the fundamental correlation persists even when we estimate it using instrumental variables. All this suggests that it is unlikely that reverse causality is the source of our results.

\subsection{Other Explanations: Investment and Cost of Capital.}

Investment opportunities in different industries may be very different. For instance, the tobacco industry in the United States uses negative external finance (see Table 1) partly because investment opportunities in the Tobacco industry are small relative to the cashflows the industry generates. It may be that our measure of dependence on external finance proxies primarily for the investment intensity of a particular industry. Furthermore, the size of the financial sector may proxy for the extent of savings in the country, and hence for the cost of capital in that country. The interaction may simply represent the fact that capital intensive firms grow faster in an environment with a lower cost of capital. While this is certainly a channel through which financial development could affect growth, it is not the channel we focus on.

If investment intensity were all that mattered, and external finance and internal finance were equally costly, the cash internally generated by industries would be irrelevant in countries that are more financially developed. All that mattered would be the size of the required investment and the cost of capital. By contrast, if there is a wedge between the cost of internal and external finance which decreases in the state of development of financial markets, the cash internally generated by industries would have its own interaction effect with financial development.

A first pass at this is to replace the interaction between dependence and financial development by the interaction between the internal cash an industry generates in the United States (normalized by property plant and equipment) and the country's financial development. Industries that generate more internal cash grow disproportionately faster in economies with underdeveloped financial markets $(\beta=-.23, \mathrm{t}=-2.4$, see Table 8 , column I). A second pass is to 
also include the interaction between an industry's investment intensity (the ratio of investment to property, plant and equipment) and the country's financial development. As Table 8 column II shows, the coefficient on the investment interaction is 0.09 , approximately half the size of the coefficient on internal cash (-0.18), though only the latter is statistically significant. Since the two coefficients are not statistically different, this supports our use of the difference between investments and cashflows as our measure of dependence on external financing throughout the paper. A final confirmation is that when we include the interaction between investment intensity and financial development in our basic regression (not reported), only the interaction between financial dependence and financial development is significant, and its coefficient is close to that estimated in the basic regression $(\beta=0.10)$.

Finally, the discussion of investments suggests that instead of using the growth rate as the dependent variable, we could use the investment intensity of an industry in other countries as the dependent variable. We obtain investment intensity by dividing the gross capital formation in the industry by value added in that industry (using U.N. data). The explanatory variables are taken from the basic regression. The coefficient of the interaction term is 0.10 and is significant at the $5 \%$ level (estimates not reported). This suggests that the higher cost of external finance in countries with poorly developed markets results in lower investment intensities in industries heavily dependent on external finance.

In sum, we test a number of alternative explanations of our results and do not find compelling evidence in their favor. Instead, the additional tests seem to add credence to the argument that financially dependent industries grow faster in countries with better developed financial markets because the cost of external finance is lower in such countries.

\section{Conclusion}

We develop a new methodology in this paper to investigate whether financial sector development has an influence on industrial growth. In doing so, we partially circumvent some of the problems with the existing cross-country methodology highlighted by Mankiw (1995). First, it is difficult to interpret observed correlations in cross-country regressions in a causal sense. Here, we push the causality debate one step further by finding evidence for a channel through which finance 
theoretically influences growth. Also, since we have multiple observations per country, we can examine situations where the direction of causality is least likely to be reversed. A second problem with the traditional methodology is that explanatory variables are multi-collinear and are measured with error. The combination of these two problems may cause a variable to appear significant when it is merely a proxy for some other variable measured with error. As a result, observed correlations can be misleading. By looking at interaction effects (with country and industry indicators) rather than direct effects, we reduce the number of variables that we rely on, as well as the range of possible alternative explanations. Third, there is the problem of limited degrees of freedom - there are fewer than two hundred countries on which the myriad theories have to be tested. Our approach partially alleviates this problem by exploiting withincountry variation in the data. Our methodology, may have wider applications, such as testing the existence of channels through which human capital can affect growth.

Apart from its methodological contribution, this paper's findings may bear on four different areas of current research. First, they suggest that financial development has a substantial supportive influence on the rate of economic growth and this works, at least partly, by reducing the cost of external finance to financially dependent firms. We should add that there is no contradiction when the lack of persistence of economic growth (Easterly, et al, (1993)) is set against the persistence of financial development. Other factors may cause (potentially serially uncorrelated) changes in a country's investment opportunity set. Finance may simply enable the pursuit of these opportunities, and thereby enhance long run growth.

Second, in the context of the literature on financial constraints, this paper provides fresh evidence that financial market imperfections have an impact on investment and growth.

Third, our results may be relevant to the current debate about what form of social security system a country should have. It has been argued that a private social security system fosters the development of capital markets. If this development has beneficial effects on a country's growth, then this might be counted as an indirect benefit of a private system.

Finally, in the context of the trade literature, the findings suggest a potential explanation for the pattern of industry specialization across countries. To the extent that financial market development (or the lack thereof) is determined by historical accident or government regulation, the existence of a well developed market in a certain country may represent a source of 
comparative advantage for that country in industries that are more dependent on external finance. Similarly, the costs imposed by a lack of financial development may differentially affect incumbent firms and new entrants, large firms versus small firms, etc. Therefore, the level of financial development may also be a factor in determining the size composition of an industry. as well as its concentration. These issues are important areas for future research. 


\section{References}

Aokı, M. AND H. PATrick Ed. 1994, The Japanese Main Bank System, Oxford University Press, New York.

BARro, R. 1991, "Economic Growth in a Cross-Section of Countries," Quarterly Journal Of Economics, CVI: 407-443.

Bekaert, G. AND C.R. HARVEy 1995, "Time-varying World Market Integration," Journal of Finance, 1995, pp. 403-44.

BARro R. AND J. LEE, 1993, "International Comparisons of Educational Attainment," NBER Working Paper.

Cameron, R. 1961, France and the Economic Development of Europe (1800-1914) (Princeton University Press: Princeton, N.J.).

Cameron, R. 1967, Banking in the Early Stages of Industrialization, Oxford University Press: New York.

Chandler, A. 1977, The Visible Hand: The Managerial Revolution in American Business Harvard University Press: Cambridge MA.

Demirguc-Kunt, A. ANd R. Levine, 1995, "Stock Markets and Financial Intermediaries: Stylized Facts," World Bank, Policy Research Working Paper.

Demirguc-Kunt, A. And V. Maksimovic, 1996, "Financial Constraints, Uses of Funds and Firm Growth: An International Comparison," World Bank Working Paper.

Diamond, D., 1984, "Financial Intermediation and Delegated Monitoring," Review of Economic Studies 393-414.

Diamond, D., 1991 "Monitoring and Reputation: the Choice Between Bank Loan and Directly Placed Debt," Journal of Political Economy 99, 689-721.

Dornbusch, R., S. Fischer, P. Samuelson, 1977 "Comparative Advantage, Trade and Payments in A Ricardian Model with a Continuum of Goods," American Economic Review. 823-839.

Easterly, W., M. Kremer, L. Pritchett, and L. Summers, 1993 "Good Policy or Good Luck? Country Growth Performance and Temporary Shocks," Journal of Monetary Economics 32 , 459-484.

FAMA, E. 1985, "What's different about banks", Joumal of Monetary Economics 15, 29-39.

Fazzari, S., R. G. Hubbard, and B. Petersen 1988, "Financing Constraints and Corporate Investment," Brookings Papers on Economic Activity 1, 141-195.

Feldstein, M. AND Horioka, C. 1980, "Domestic Saving and International Capital Flows," The Economic Journal 90: 314-329. 
French, K. AND J. Poterba 1991, "Investor Diversification and International Equity Market, ${ }^{n}$ American Economic Review 81, 222-6.

Gerschenkron, A. 1962 Economic Backwardness in Historical Perspective Harvard University Press, Cambridge, MA.

Goldsmith, R. 1969 Financial Structure and Development Yale University Press, New Haven.

Holmstrom Bengt, And J. Tirole, 1993, "Market Liquidity and Performance Monitoring”, Journal of Political Economy, Vol. 101, No. 4, 678-709.

JAMES, C. 1987, "Some Evidence on the Uniqueness of Bank Loans", Journal of Financial Economics 7, 217-235.

Kaplan, S. And L. Zingales , 1996, "Do Investment-Casflow Sensitivities Provide Useful Measures of Financing Constraints?" University of Chicago, working paper.

Kindleberger, C. 1993 A Financial History of Western Europe Oxford University Press, New York.

King, R. AND R. Levine , 1993a, "Finance and Growth: Schumpeter Might Be Right", The Quarterly Journal of Economics, Vol. CVIII, No. 3, 681-737.

King, R. AND R. LEVINE , 1993b, "Finance, Entrepreneurship, and Growth", Journal of Monetary Economics, 513-542.

Klenow, P. , 1995, "Ideas vs. Rival Human Capital: Industry Evidence on Growth Models," University of Chicago working paper.

Kormendi, R. And P. Meguire , 1985, "Macroeconomic Determinants of Growth," Journal of Monetary Economics, Vol. XVI, 141-163.

la Porta, R., F. Lopez de Silanes, A. Shleifer, and R. Vishny (1996) "Law and Finance," NBER Working Paper 5661.

Levine, R. , 1991, “ Stock Markets, Growth, and Tax Policy”, Journal of Finance, XLVI 1445-1465.

Levine, R. And D. Renelt , 1993, "A Sensitivity Analysis of Cross-Countries Growth Regressions", American Economic Review, Vol. LXXXII, 942-963.

Mankiw, G. , 1995, "The Growth of Nations", Brookings Papers on Economic Activity, Vol 1.

Mankiw, G., D. Romer, AND D. WeIL , 1992, "A Contribution to the Empirics of Economic Growth," The Quarterly Journal of Economics, Vol. CVII, 407-437.

MAYER, C. 1990, "Financial Systems, Corporate Finance, and Economic Development," in R. Glenn Hubbard, ed.: Asymmetric Information, Corporate Finance and Investment, The University of Chicago Press, Chicago, IL. 
MCKinnon, R. 1973, Money and Capital in Economic Development The Brookings Institution, Washington, D.C..

Petersen, M. And R. Rajan 1996, "Trade Credit: Some theories and evidence", mimeo, University of Chicago.

MYers, S. 1977, "Determinants of Corporate Borrowing", Journal of Financial Economics, 5: $146-175$.

MyerS, S.C. AND N.S. Majluf 1984, "Corporate Financing and Investment Decisions when Firms have Information that Investors Do Not Have" Journal of Financial Economics, 13, 187-222.

NoRTh, D. 1981, Structure and Change in Economic History New York, Norton.

Pagano, M., Panetta, F. and L. Zingales 1995, "Why Do Companies Go Public? An Empirical Analysis," NBER Working Paper \#5367.

Paxson, C. 1996, "Saving and Growth: Evidence from Micro Data," Princeton Working Paper.

Rajan, R. And L. Zingales 1995, "What Do We Know About Capital Structure: Some Evidence From International Data" Journal of Finance, December.

Schumpeter, J. A. 1911, A Theory of Economic Development Harvard University Press: Cambridge, MA.

Stein, J. 1989, "Efficient Capital Markets, Inefficient Firms: A Model of Myopic Behavior", Quarterly Journal of Economics, 655-669. 
Table 1:

\section{Pattern of external financing and investment across industries in the U.S. during the 1980s}

The table reports the median level of external financing, equity financing, and investments for ISIC industries during the 1980s. External finance is the fraction of capital expenditures not financed with cash flow from operations. Cash flow from operations is broadly defined as the sum of Compustat funds from operations (item \# 110), decreases in inventories, decreases in receivables, and increases in payables. Equity finance is the ratio of the net amount of equity issues to capital expenditures. Investment is the ratio of capital expenditures to net property plan and equipment. Mature firms are defined as firms that have been public for at least 10 years, correspondingly young firms are defined as firms that went public less than 10 years ago. The IPO year is defined as the first year in which a company starts to be traded on the NYSE, AMEX, or NASDAQ. All the information is obtained from the flow of funds data in Compustat, except for the SIC code which is obtained from CRSP and then matched with the ISIC code.

\begin{tabular}{|c|c|c|c|c|c|c|c|c|c|c|}
\hline \multirow[b]{2}{*}{$\begin{array}{l}\text { ISIC } \\
\text { code }\end{array}$} & \multirow[b]{2}{*}{ Industrial sectors } & \multicolumn{3}{|c|}{ All Companies } & \multicolumn{3}{|c|}{ Mature Companies } & \multicolumn{3}{|c|}{ Young Companies } \\
\hline & & $\begin{array}{l}\text { External } \\
\text { Finance }\end{array}$ & $\begin{array}{l}\text { Equity } \\
\text { Finance }\end{array}$ & Capex & $\begin{array}{c}\text { External } \\
\text { Finance }\end{array}$ & $\begin{array}{l}\text { Equity } \\
\text { Finance }\end{array}$ & $\begin{array}{l}\text { Capex } \\
\text { Finance }\end{array}$ & $\begin{array}{l}\text { External } \\
\text { Finance }\end{array}$ & Equity & Capex \\
\hline 311 & Food products & 0.14 & 0.00 & 0.26 & -0.05 & 0.00 & 0.25 & 0.66 & 0.28 & $0 . \overline{33}$ \\
\hline 313 & Beverages & 0.08 & 0.00 & 0.26 & -0.15 & 0.00 & 0.28 & 0.63 & 0.00 & 0.26 \\
\hline 314 & Tobacco & -0.45 & -0.08 & 0.23 & -0.38 & -0.21 & 0.24 & . & . & . \\
\hline 321 & Textile & 0.40 & 0.01 & 0.25 & 0.14 & 0.00 & 0.24 & 0.66 & 0.36 & 0.26 \\
\hline 3211 & Spinning & -0.09 & -0.09 & 0.16 & & . & . & - & . & . \\
\hline 322 & Apparel & 0.03 & 0.00 & 0.31 & -0.02 & -0.01 & 0.27 & 0.27 & 0.15 & 0.37 \\
\hline 323 & Leather & -0.14 & 0.00 & 0.21 & -1.33 & 0.00 & 0.27 & & . & . \\
\hline 324 & Footwear & -0.08 & 0.04 & 0.25 & -0.57 & 0.00 & 0.23 & 0.65 & 0.20 & 0.26 \\
\hline 331 & Wood Products & 0.28 & 0.04 & 0.26 & 0.25 & 0.01 & 0.23 & 0.34 & 0.01 & 0.40 \\
\hline 332 & Furniture & 0.24 & 0.01 & 0.25 & 0.33 & 0.01 & 0.17 & 0.68 & 0.26 & 0.29 \\
\hline 341 & Paper and products & 0.18 & 0.02 & 0.24 & 0.10 & 0.02 & 0.23 & 0.57 & 0.11 & 0.29 \\
\hline 3411 & Pulp, paper & 0.15 & 0.02 & 0.20 & 0.13 & 0.01 & 0.21 & 0.22 & 0.01 & 0.20 \\
\hline 342 & Printing \& publishing & 0.20 & 0.03 & 0.39 & 0.14 & 0.00 & 0.33 & 0.60 & 0.20 & 0.41 \\
\hline 3511 & Basic exclud fert & 0.25 & 0.12 & 0.30 & 0.08 & 0.04 & 0.24 & 0.79 & 0.36 & 0.29 \\
\hline 3513 & Synthetic resins & 0.16 & 0.03 & 0.30 & -0.23 & -0.09 & 0.20 & 0.79 & 0.25 & 0.45 \\
\hline 352 & Other chemicals & 0.22 & 0.02 & 0.31 & -0.18 & 0.00 & 0.25 & 1.35 & 0.33 & 0.46 \\
\hline 3522 & Drugs & 1.49 & 0.76 & 0.44 & 0.03 & 0.00 & 0.32 & 2.06 & 1.15 & 0.47 \\
\hline 353 & Pet. refineries & 0.04 & 0.00 & 0.22 & -0.02 & -0.00 & 0.22 & 0.85 & 0.27 & 0.28 \\
\hline 354 & Pet.\& coal products & 0.33 & 0.06 & 0.23 & 0.16 & 0.01 & 0.26 & -0.26 & 0.30 & 0.22 \\
\hline 355 & Rubber products & 0.23 & 0.11 & 0.28 & -0.12 & -0.01 & 0.21 & 0.50 & 0.32 & 0.32 \\
\hline 356 & Plastic products & 1.14 & 0.26 & 0.44 & . & . & . & 1.14 & 0.96 & 0.48 \\
\hline 361 & Pottery & -0.15 & 0.11 & 0.20 & . & . & . & 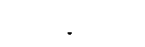 & 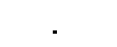 & . \\
\hline 362 & Glass & 0.53 & 0.02 & 0.28 & 0.03 & -0.02 & 0.28 & 1.52 & 0.48 & 0.33 \\
\hline 369 & Non metal products & 0.06 & 0.01 & 0.21 & 0.15 & 0.03 & 0.22 & -0.03 & 0.00 & 0.26 \\
\hline
\end{tabular}




\begin{tabular}{|c|c|c|c|c|c|c|c|c|c|c|}
\hline \multirow[b]{2}{*}{$\begin{array}{l}\text { ISIC } \\
\text { code }\end{array}$} & \multirow[b]{2}{*}{ Industrial sectors } & \multicolumn{3}{|c|}{ All Companies } & \multicolumn{3}{|c|}{ Mature Companies } & \multicolumn{3}{|c|}{ Young Companies } \\
\hline & & $\begin{array}{l}\text { External } \\
\text { Finance }\end{array}$ & $\begin{array}{c}\text { Equity } \\
\text { Finance }\end{array}$ & Capex & $\begin{array}{l}\text { External } \\
\text { Finance }\end{array}$ & $\begin{array}{c}\text { Equity } \\
\text { Finance }\end{array}$ & $\begin{array}{c}\text { Capex } \\
\text { Finance }\end{array}$ & $\begin{array}{c}\text { External } \\
\text { Finance }\end{array}$ & Equity & Capex \\
\hline 371 & Iron and steel & 0.09 & 0.01 & 0.18 & 0.09 & 0.02 & 0.16 & 0.26 & 0.12 & 0.19 \\
\hline 372 & Non-ferrous metal & 0.01 & 0.02 & 0.22 & 0.07 & 0.00 & 0.21 & 0.46 & 0.61 & 0.24 \\
\hline 381 & Metal products & 0.24 & 0.02 & 0.29 & 0.04 & 0.00 & 0.25 & 0.87 & 0.25 & 0.34 \\
\hline 382 & Machinery & 0.45 & 0.11 & 0.29 & 0.22 & 0.04 & 0.25 & 0.75 & 0.41 & 0.33 \\
\hline 3825 & Office, computing & 1.06 & 0.67 & 0.60 & 0.26 & 0.05 & 0.38 & 1.16 & 0.78 & 0.64 \\
\hline 383 & Elect. machinery & 0.77 & 0.36 & 0.38 & 0.23 & 0.02 & 0.29 & 1.22 & 0.78 & 0.46 \\
\hline 3832 & Radio & 1.04 & 0.46 & 0.42 & 0.39 & 0.02 & 0.30 & 1.35 & 0.74 & 0.48 \\
\hline 384 & Transp. Eq. & 0.31 & 0.05 & 0.31 & 0.16 & 0.01 & 0.28 & 0.58 & 0.16 & 0.31 \\
\hline 3841 & Ship & 0.46 & 0.02 & 0.43 & 0.04 & -0.04 & 0.34 & 1.05 & 0.52 & 0.56 \\
\hline 3843 & Motor veichle & 0.39 & 0.01 & 0.32 & 0.11 & 0.00 & 0.33 & 0.76 & 0.02 & 0.32 \\
\hline 385 & Professional goods & 0.96 & 0.62 & 0.45 & 0.19 & 0.03 & 0.33 & 1.63 & 0.94 & 0.52 \\
\hline 390 & Other ind. & 0.47 & 0.16 & 0.37 & -0.05 & 0.01 & 0.28 & 0.80 & 0.37 & 0.49 \\
\hline
\end{tabular}


Table 2:

\section{Financial development across countries.}

The equity market capitalization over GDP is the total value of publicly traded equity at the end of 1980 as reported by the IFC divided by the Gross Domestic Product that year. The level of domestic credit is the sum of assets held by the monetary authority and depository institutions but excluding interbank deposits (IFS line 92a-92f but not 92 e) divided by GDP. The ratio of private credit to domestic credit is the proportion of domestic credit represented by claims against the private sector (IFS line 92d). The logarithm of per capita income is obtained by dividing the 1980 GDP in dollars by a country's population as reported by IFS. The exchange rates are also from the IFS.

\begin{tabular}{lcccc}
\hline \hline Country & $\begin{array}{c}\text { Equity market cap. } \\
\text { over GDP }\end{array}$ & $\begin{array}{c}\text { Domestic credit } \\
\text { over GDP }\end{array}$ & $\begin{array}{c}\text { Private credit } \\
\text { over domestic credit }\end{array}$ & $\begin{array}{c}\text { Log of per } \\
\text { capita income }\end{array}$ \\
\hline Australia & 0.38 & 0.44 & 0.63 & 9.197 \\
Austria & 0.03 & 0.97 & 0.79 & 9.165 \\
Bangladesh & 0.00 & 0.20 & 0.35 & 4.793 \\
Belgium & 0.09 & 0.56 & 0.51 & 9.326 \\
Brazil & 0.05 & 0.28 & 0.83 & 7.409 \\
Canada & 0.46 & 0.52 & 0.86 & 9.258 \\
Chile & 0.34 & 0.40 & 0.89 & 7.836 \\
Colombia & 0.05 & 0.16 & 0.89 & 7.047 \\
Costa Rica & 0.04 & 0.49 & 0.52 & 7.676 \\
Denmark & 0.09 & 0.47 & 0.89 & 9.408 \\
Egypt & 0.01 & 0.73 & 0.29 & 6.332 \\
Finland & 0.06 & 0.46 & 1.04 & 9.228 \\
France & 0.10 & 0.60 & 0.91 & 9.336 \\
Germany & 0.09 & 0.99 & 0.79 & 9.421 \\
Greece & 0.08 & 0.66 & 0.66 & 8.246 \\
India & 0.05 & 0.45 & 0.55 & 5.480 \\
Indonesia & 0.00 & 0.13 & 1.50 & 6.207 \\
Israel & 0.35 & 0.83 & 0.80 & 8.181 \\
Italy & 0.07 & 0.90 & 0.46 & 8.773 \\
Jamaica & 0.02 & 0.46 & 0.32 & 7.111 \\
Japan & 0.30 & 1.00 & 0.85 & 9.201 \\
Jordan & 0.50 & 0.67 & 0.81 & 7.012 \\
Kenya & 0.00 & 0.28 & 0.73 & 6.034 \\
Korea & 0.08 & 0.55 & 0.91 & 7.250 \\
Malaysia & 0.65 & 0.53 & 0.91 & 7.428 \\
Mexico & 0.07 & 0.32 & 0.52 & 6.883 \\
Morocco & 0.02 & 0.38 & 0.41 & \\
\hline \hline
\end{tabular}




\begin{tabular}{lcccc}
\hline \hline Country & $\begin{array}{c}\text { Equity market cap. } \\
\text { over GDP }\end{array}$ & $\begin{array}{c}\text { Domestic credit } \\
\text { over GDP }\end{array}$ & $\begin{array}{c}\text { Private credit } \\
\text { over domestic credit }\end{array}$ & $\begin{array}{c}\text { Log of per } \\
\text { capita income }\end{array}$ \\
\hline Netherlands & 0.19 & 0.72 & 0.84 & 9.320 \\
New Zealand & 0.33 & 0.26 & 0.72 & 8.921 \\
Norway & 0.06 & 0.57 & 0.60 & 9.505 \\
Pakistan & 0.03 & 0.50 & 0.50 & 5.671 \\
Peru & 0.06 & 0.22 & 0.48 & 6.736 \\
Philippines & 0.10 & 0.36 & 0.77 & 6.591 \\
Portugal & 0.01 & 0.81 & 0.64 & 7.741 \\
Singapore & 1.62 & 0.34 & 1.67 & 8.447 \\
South Africa & 1.20 & 0.31 & 0.84 & 7.972 \\
Spain & 0.09 & 0.93 & 0.81 & 8.534 \\
Sri Lanka & 0.06 & 0.38 & 0.56 & 5.528 \\
Sweden & 0.11 & 0.68 & 0.61 & 9.573 \\
Turkey & 0.01 & 0.34 & 0.41 & 6.985 \\
UK & 0.38 & 0.40 & 0.63 & 9.170 \\
US & 0.53 & 0.49 & 0.72 & 9.338 \\
Venezuela & 0.05 & 0.29 & 1.03 & 8.288 \\
Zimbabwe & 0.45 & 0.56 & 0.53 & 6.088 \\
\hline \hline
\end{tabular}


Table 3:

\section{Summary Statistics.}

Industry real growth is the annual compounded growth rate in real value added estimated for the period 1980-1990 for each ISIC industry in each country. The growth in the number of firms is the difference in the log of ending period firms less the log of firms in the beginnning of period. The average size of firms in the industry is obtained by dividing the value added in the industry by the number of firms, and the growth in average size is obtained again as a difference in logs. The industry's share of total value added is computed dividing the 1980 value added of the industry by the total value added in manufacturing that year. All these data come from the United Nations statistics. External finance is the median fraction of capital expenditures not financed with cash flow from operations for each industry. Cash flow from operations is broadly defined as the sum of Compustat funds from operations (item \# 110), decreases in inventories, decreases in receivables, and increases in payables. Equity finance is the median ratio of the net amount of equity issues to capital expenditures. Both these variables have been constructuted by the authors using Compustat. Investment's share of GDP in 1980 is from Barro and Lee (1994). The log of the 1980 per capita income in U.S. dollars is from the IFS. The average years of schooling in the population over 25 years is from Barro and Lee (1994). Financial development is the sum of the ratio of total market value of publicly traded equity to GDP and the ratio of domestic credit to GDP (from IFS and IFC). The origin of the legal system has four indicator variables from La Porta et al. (1996). Efficiency of the judicial system is an index from 0 to 10 developed by Business International Corporation that assesses the efficency and integrity of the legal environment. The accounting standards is an index developed by the Center for International Financial Analysis \& Research ranking the amount of disclosure of companies' annual reports in each country. The last two variables are taken from La Porta et al. (1996).

\begin{tabular}{lcccccc}
\hline \hline Variable & Mean & Median & Std. Dev & Min. & Max. & Nobs. \\
\hline Industry annual real growth & & & & & & \\
Grow'th in number of firms in industry & 0.035 & 0.029 & 0.090 & -0.447 & 1.000 & 1217 \\
Growth in average firms' size in industry & 0.000 & 0.008 & 0.047 & -0.209 & 0.295 & 1004 \\
Industry's share of total value added & 0.016 & 0.009 & 0.021 & 0.000 & 0.224 & 1217 \\
Industry external finance dependence & 0.319 & 0.231 & 0.406 & -0.451 & 1.492 & 36 \\
Industry equity finance dependence & 0.112 & 0.024 & 0.206 & -0.090 & 0.764 & 36 \\
Investment's share of GDP in 1980 & 0.236 & 0.250 & 0.076 & 0.033 & 0.377 & 43 \\
Log per capita income in 1980 in dollars & 7.814 & 7.883 & 1.340 & 4.793 & 9.573 & 43 \\
Average years of schooling & 5.900 & 5.442 & 2.829 & 1.681 & 12.141 & 41 \\
Financial development & 0.718 & 0.654 & 0.380 & 0.132 & 1.962 & 43 \\
English law origin & 0.333 & 0.000 & 0.478 & 0.000 & 1.000. & 39 \\
French law origin & 0.462 & 0.000 & 0.505 & 0.000 & 1.000 & 39 \\
German law origin & 0.103 & 0.000 & 0.307 & 0.000 & 1.000 & 39 \\
Scandinavian law origin & 0.103 & 0.000 & 0.307 & 0.000 & 1.000 & 39 \\
Efficiency of judicial system & 7.716 & 7.500 & 2.036 & 2.500 & 10.000 & 39 \\
Accounting Standards & 61.937 & 63.000 & 12.600 & $\mathbf{2 4 . 0 0 0}$ & $\mathbf{8 3 . 0 0 0}$ & 32 \\
\hline \hline
\end{tabular}


Table 4:

\section{Financial dependence and industry growth.}

The dependent variable is the annual compounded growth rate in real value added estimated for the period 1980-1990 for each ISIC industry in each country. Investment's share of GDP in 1980 is from Barro and Lee (1994). The log of the 1980 per capita income in U.S. dollars is from IFS. The average years of schooling in the population over 25 years is from Barro and Lee (1994). Financial development is the sum of the ratio of total market value of publicly traded equity to GDP and the ratio of domestic credit to GDP. The industry's share of total value added is computed dividing the 1980 value added of the industry by the total value added in manufacturing that year (both these data come from the United Nations statistics). External dependence is the fraction of capital expenditures not financed with internal funds by U.S. firms in the same industry during the 1980s. The interaction variable is the product of external dependence and financial development. The coefficients for the constant terms and indicator variables are not reported. Heteroscedasticity robust standard errors are reported in brackets.

\begin{tabular}{|c|c|c|c|c|}
\hline Variable & $\overline{\text { OLS }}$ & $\begin{array}{c}\text { Fixed Country } \\
\text { Effects }\end{array}$ & $\begin{array}{c}\text { Fixed Industry } \\
\text { Effects }\end{array}$ & $\begin{array}{c}\text { Fixed effects for } \\
\text { both Country and Industry }\end{array}$ \\
\hline $\begin{array}{l}\text { Investment's share of GDP in } \\
1980\end{array}$ & $\begin{array}{c}0.203 \\
(0.057)\end{array}$ & & $\begin{array}{c}0.199 \\
(0.055)\end{array}$ & \\
\hline $\begin{array}{l}\text { Log per capita income in } 1980 \\
\text { in dollars }\end{array}$ & $\begin{array}{c}-0.019 \\
(0.004)\end{array}$ & & $\begin{array}{c}-0.018 \\
(0.004)\end{array}$ & \\
\hline $\begin{array}{l}\text { Average years of schooling in } \\
\text { population over } 25 \text { years }\end{array}$ & $\begin{array}{c}-0.001 \\
(0.002)\end{array}$ & & $\begin{array}{c}-0.001 \\
(0.002)\end{array}$ & \\
\hline Financial development & $\begin{array}{c}0.013 \\
(0.009)\end{array}$ & & $\begin{array}{c}0.014 \\
(0.009)\end{array}$ & \\
\hline $\begin{array}{l}\text { Industry's share of total value } \\
\text { added in manufacturing in } 1980\end{array}$ & $\begin{array}{c}-0.607 \\
(0.181)\end{array}$ & $\begin{array}{c}-0.607 \\
(0.188)\end{array}$ & $\begin{array}{c}-0.907 \\
(0.227)\end{array}$ & $\begin{array}{c}-0.912 \\
(0.238)\end{array}$ \\
\hline $\begin{array}{l}\text { Dependence of industry from } \\
\text { external finance in the U.S. }\end{array}$ & $\begin{array}{c}-0.034 \\
(0.021)\end{array}$ & $\begin{array}{c}-0.035 \\
(0.020)\end{array}$ & & \\
\hline $\begin{array}{l}\text { Interaction (external dependence } \\
\text { financial development) }\end{array}$ & $\begin{array}{c}0.069 \\
(0.024)\end{array}$ & $\begin{array}{c}0.067 \\
(0.024)\end{array}$ & $\begin{array}{c}0.071 \\
(0.023)\end{array}$ & $\begin{array}{c}0.069 \\
(0.022)\end{array}$ \\
\hline $\begin{array}{l}\text { R-squared } \\
\text { Number of observations }\end{array}$ & $\begin{array}{c}0.083 \\
1171\end{array}$ & $\begin{array}{l}0.233 \\
1217\end{array}$ & $\begin{array}{c}0.144 \\
1171\end{array}$ & $\begin{array}{c}0.290 \\
1217\end{array}$ \\
\hline
\end{tabular}


Table 5:

\section{Industry growth and the composition of capital markets.}

The dependent variable is the annual compounded growth rate in real value added estimated for the period 1980-1990 for each ISIC industry in each country. The industry's share of total value added is computed dividing the 1980 value added of the industry by the total value added in manufacturing that year (both these data come from the United Nations statistics). External dependence is the fraction of capital expenditures not financed with internal funds by U.S. firms in the same industry during the 1980s. Equity dependence is the ratio of equity finance to total external finance by U.S. firms in the same industry in the 1980s. Public credit is domestic credit less credit to the private sector. All regressions contain fixed country and industry effects (coefficient estimates not reported). Heteroscedasticity robust standard errors are reported in brackets.

\begin{tabular}{lcc}
\hline \hline Variable & I & II \\
\hline Industry's share of total value & -0.932 & -0.931 \\
added in manufacturing in 1980 & $(0.237)$ & $(0.237)$ \\
& & \\
Interaction 1 (external dependence & 0.107 & 0.107 \\
X financial development) & $(0.034)$ & $(0.034)$ \\
& & \\
Interaction 2 (external dependence & -0.066 & -0.066 \\
X stock market/GDP) & $(0.032)$ & $(0.032)$ \\
& & \\
Interaction 2' (equity dependence & & -0.007 \\
X stock market/GDP) & & $(0.014)$ \\
& & \\
Interaction 3 (external dependence & -0.158 & -0.158 \\
X public credit/GDP) & $0.046)$ & $(0.046)$ \\
& & \\
R-squared & 0.294 & 0.295 \\
Number of observations & 1217 & 1217 \\
\hline \hline
\end{tabular}


Table 6:

\section{Robustness.}

The dependent variable is the annual compounded growth rate in real value added estimated for the period 1980-1990 for each ISIC industry in each country. The industry's share of total value added is computed dividing the 1980 value added of the industry by the total value added in manufacturing that year (both these data come from the United Nations statistics). External dependence is the fraction of capital expenditures not financed with internal funds by U.S. firms in the same industry during the 1980s. In column I this ratio is computed only for companies that have been public for at least 10 years, in column II the ratio is computed for companies that have gone public in the last 9 years, in column III is computed for U.S. firms during the 1970s. In columns IV and V external dependence is computed for all companies (as in the basic specification), but in columns IV external dependence is interacted with the level of accounting standard of each country (divided by 100) and in column $V$ the regression is restricted to industries that had a share of total value added in manufacturing above the median. All regressions contain fixed country and industry effects (coefficient estimates not reported). Heteroscedasticity robust standard errors are reported in brackets.

\begin{tabular}{lccccc}
\hline \hline Variable & I & II & III & IV & V \\
\hline Industry's share of total value & -0.906 & -0.924 & -0.871 & -0.658 & -0.602 \\
added in manufacturing in 1980 & $(0.252)$ & $(0.277)$ & $(0.238)$ & $(0.200)$ & $(0.199)$ \\
& & & & & \\
Interaction (external dependence & 0.050 & 0.042 & 0.100 & 0.158 & 0.062 \\
financial development) & $(0.019)$ & $(0.021)$ & $(0.049)$ & $(0.036)$ & $(0.023)$ \\
& & & & & \\
R-squared & 0.273 & 0.277 & 0.279 & 0.346 & 0.499 \\
Number of observations & 1118 & 1085 & 1179 & 1032 & 591 \\
& & & & & \\
\hline \hline
\end{tabular}


Table 7:

\section{Is financial dependence a proxy for other variables?}

The dependent variable is the annual compounded growth rate in real value added estimated for the period 1980-1990 for each ISIC industry in each country. The industry's share of total value added is computed dividing the 1980 value added of the industry by the total value added in manufacturing that year (both these data come from the United Nations statistics). External dependence is the fraction of capital expenditures not financed with internal funds by U.S. firms in the same industry during the 1980s. Column I adds to the basic specification the interaction between external dependence and a country's human capital. Column II adds to the basic specification the interaction between external dependence and a country's level of economic development (log per capita income). Column III adds to the basic specification a variable multiplying our fundamental interaction variable and a dummy equal to one if an industry is above median size in a country with above median weighted average financial dependence. Column IV adds to the basic specification the interaction between external dependence and a country's weighted average external dependence. The weighted average external dependence is the sum over all industries in a country of each industry's share of value added in 1980 weighted by the external dependence. Column V estimates the basic specification for industries that in 1980 were less than the median size in their respective countries. Column VI estimates the basic specification using instrumental variables. The instruments are the origin of a country legal system and the efficiency level of a country's judicial system. All regressions contain fixed country and industry effects (not reported). Heteroscedasticity robust standard errors are reported in brackets.

\begin{tabular}{|c|c|c|c|c|c|c|}
\hline Variable & $\bar{I}$ & $\overline{\overline{I I}}$ & III & IV & $\overline{\mathrm{V}}$ & $\overline{\mathrm{VI}}$ \\
\hline $\begin{array}{l}\text { Industry's share of total value } \\
\text { added in manufacturing in } 1980\end{array}$ & $\begin{array}{c}-0.948 \\
(0.249)\end{array}$ & $\begin{array}{c}-0.944 \\
(0.237)\end{array}$ & $\begin{array}{c}-0.903 \\
(0.241)\end{array}$ & $\begin{array}{c}-0.892 \\
(0.240)\end{array}$ & $\begin{array}{c}-5.890 \\
(1.608)\end{array}$ & $\begin{array}{c}-0.552 \\
(0.140)\end{array}$ \\
\hline $\begin{array}{l}\text { Interaction } 1 \text { (external dependence } \\
\mathrm{X} \text { financial development) }\end{array}$ & $\begin{array}{l}0.063 \\
(0.022)\end{array}$ & $\begin{array}{l}0.049 \\
(0.022)\end{array}$ & $\begin{array}{l}0.072 \\
(0.027)\end{array}$ & $\begin{array}{l}0.075 \\
(0.037)\end{array}$ & $\begin{array}{c}0.074 \\
(0.033)\end{array}$ & $\begin{array}{c}0.041 \\
(0.020)\end{array}$ \\
\hline $\begin{array}{l}\text { Interaction } 2 \text { (external dependence } \\
\mathrm{X} \text { average years of schooling) }\end{array}$ & $\begin{array}{c}0.004 \\
(0.003)\end{array}$ & & & & & \\
\hline $\begin{array}{l}\text { Interaction } 3 \text { (external dependence } \\
\mathrm{X} \text { log of per capita income in } 1980 \text { ) }\end{array}$ & & $\begin{array}{c}0.013 \\
(0.008)\end{array}$ & & & & \\
\hline $\begin{array}{l}\text { Interaction } 1 \mathrm{X} \text { dummy if industry } \\
\text { above median in country with } \\
\text { above median fin. dependence }\end{array}$ & & & $\begin{array}{l}-0.004 \\
(0.013)\end{array}$ & & & \\
\hline $\begin{array}{l}\text { Interaction } 4 \text { (external dependence } \\
\mathrm{X} \text { weighted ave. external dependence) }\end{array}$ & & & & $\begin{array}{c}-0.101 \\
(0.324)\end{array}$ & & \\
\hline $\begin{array}{l}\text { R-squared } \\
\text { Number of observations }\end{array}$ & $\begin{array}{c}0.286 \\
1171\end{array}$ & $\begin{array}{c}0.295 \\
1217\end{array}$ & $\begin{array}{c}0.290 \\
1217\end{array}$ & $\begin{array}{c}0.290 \\
1171\end{array}$ & $\begin{array}{c}0.359 \\
626\end{array}$ & $\begin{array}{c}0.113 \\
1149\end{array}$ \\
\hline
\end{tabular}


Table 8:

\section{Cash Flow and Investments}

The dependent variable is the annual compounded growth rate in real value added estimated for the period 1980-1990 for each ISIC industry in each country. The industry's share of total value added is computed dividing the 1980 value added of the industry by the total value added in manufacturing that year (both these data come from the United Nations). Internal cash flow is the ratio of cash flow from operations broadly defined (see text) to net property plant and equipment for U.S. firms in the same industry. Investment intensity is the ratio of capital expenditures to property plant and equipment for U.S. firms in the same industry. All regressions contain fixed country and industry effects (coefficient estimates not reported). Heteroscedasticity robust standard errors are reported in brackets.

\begin{tabular}{lcc}
\hline \hline Variable & I & II \\
\hline $\begin{array}{lcc}\text { Industry's share of total value } \\
\text { added in manufacturing in 1980 }\end{array}$ & -0.873 & -0.893 \\
& $(0.236)$ & $(0.238)$ \\
Interaction (internal cash flow & -0.229 & -0.187 \\
X financial development) & $(0.085)$ & $(0.090)$ \\
& & \\
Interaction 2 (investment intensiveness & & 0.093 \\
X financial development) & & $(0.096)$ \\
R-squared & 0.288 & 0.289 \\
Number of observations & 1217 & 1217 \\
\hline \hline
\end{tabular}


Figure 1:

\section{Life Cycle of External Financing and Investments}

The graph plots the median level of external financing, equity financing, and investments in the U.S. across 3-digit SIC industries as a function of the number of years since the IPO. External finance is the amount of investments (CAPEX) not financed with cash flow from operations, reduction in inventories, or decreases in trade credit. Equity finance is the net amount of funds raised through equity issues divided by the amount of investments. Investment is the ratio of CAPEX to net property, plant and equipment. The IPO year is defined as the first year in which a company starts to be traded on the NYSE, AMEX, or NASDAQ. All the information is obtained from the flow of funds data in Compustat, except for the SIC code which is from CRSP.

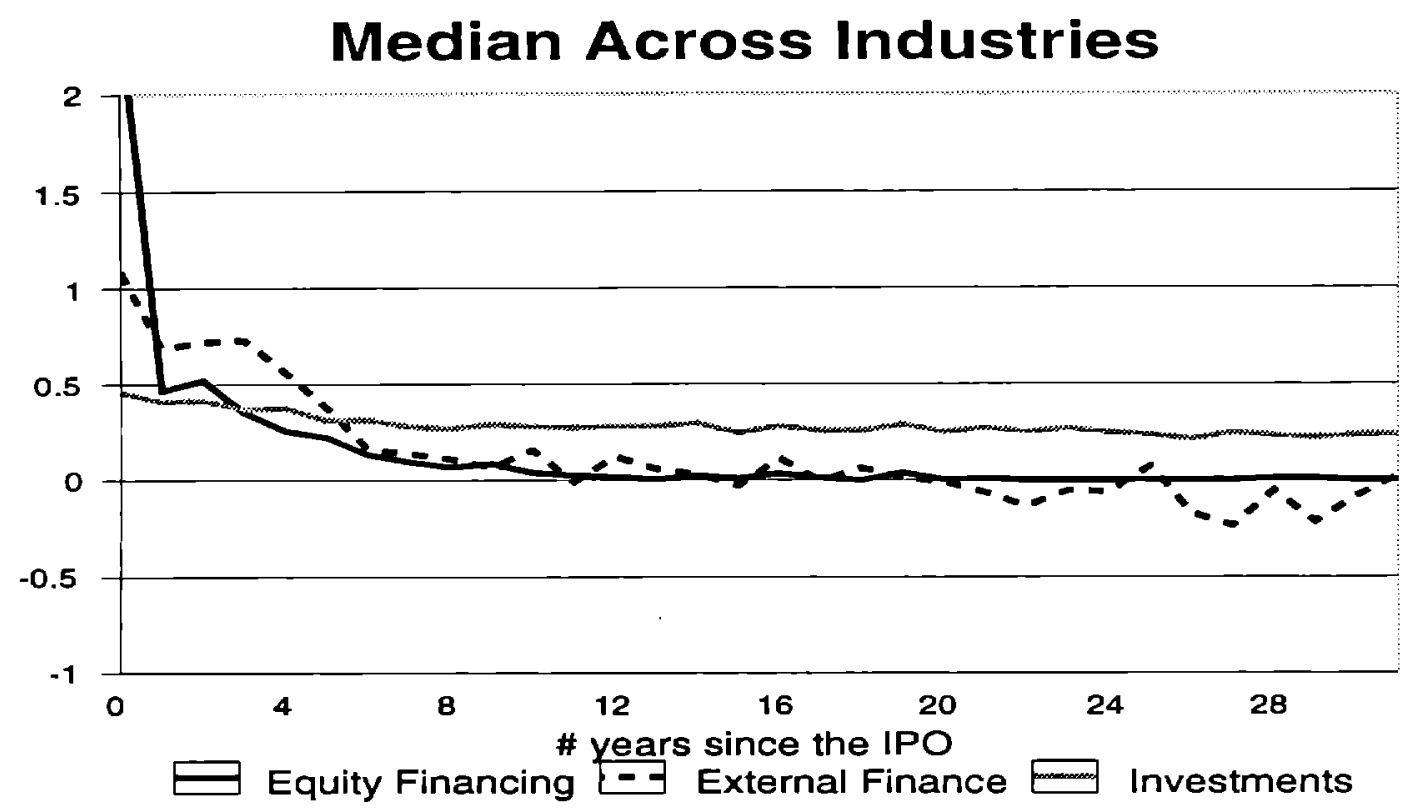


Figure 2:

\section{Life Cycle of External Financing and Investments in Two Different Industries}

The two graphs plot the average level of external financing, equity financing, and investments in the U.S. for two 3-digit industries. External finance is the amount of investments (CAPEX) not financed with cash flow from operations, reduction in inventories, or decreases in trade credit. Equity finance is the net amount of funds raised through equity issues divided by the amount of investments. Investment is the ratio of CAPEX to net property, plant and equipment. The IPO year is defined as the first year in which a company starts to be traded on the NYSE, AMEX, or NASDAQ. All the information is obtained from the flow of funds data in Compustat, except for the SIC code which is from CRSP. Computer is SIC code 357, Steel is SIC code 331.
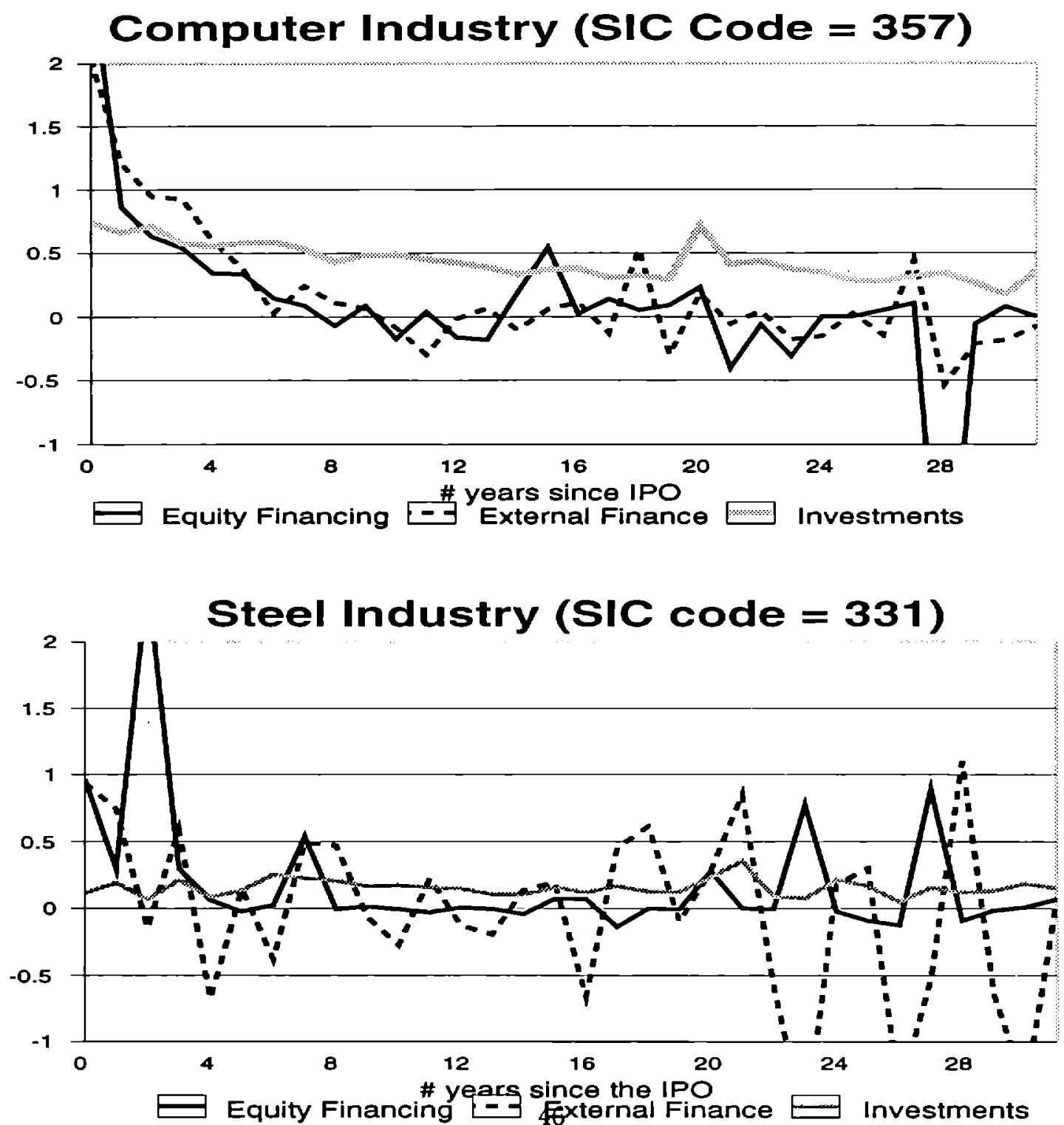